\title{
Grønland: \\ Lad Rigsfællesskabet bestå
}

Søren Espersen

\section{Det er synd, at det er lykkedes en lille gruppe grønlandske politikere at manipulere den grøn- landske befolkning til at tro, at alt ondt kommer fra Danmark}

Grønland og Rigsfællesskabet har optaget mig og engageret mig i al min tid. Jeg fik så at sige Grønland lige ind ad døren derhjemme i Himmerland, da jeg var 5 år gammel i 1958 og en af mine søstre kom slæbende med en eskimo-dreng, som hun havde fundet på Tønder Seminarium. Han var gået frivilligt med et år senere stod brylluppet. De er stadig, 50 år efter, lykkeligt gift, og han er netop fyldt 75 .

Han blev jo dermed min bror, og hans familie deroppe i Grønland har vi lært at kende, og vi har i gennem alle årene snakket og grinet og råbt og diskuteret om Grønland, om Danmark, om Rigsfællesskabet, og jeg har i årenes løb haft glæde af gode Grønlandsrejser. Og engagementet hos mig omkring Grønland er aldeles usvækket...!

Op til en debat jeg for nylig havde med Jonathan Motzfeldt i Grønlandsk Selskab, fløj det pludselig igennem mit hoved: Hvornår har man i de seneste mange år hørt en grønlandsk politiker formulere sætningen: "Hvad kan vi grønlændere gøre for Rigsfællesskabet?”

Min påstand er, at en sådan sætning ikke i årevis er blevet fremsat.

Derimod har man gang på gang hørt danske politikere sige: "Hvad kan vi gøre for Rigsfællesskabet” og som regel fulgt op af: "Fortæl os det - så vi sammen kan gøre det så godt som muligt." Fra de grønlandske politikere har man derimod, når sagen drejer sig om Danmark og Rigsfællesskabet, mest hørt klynkeri; en vedholdende uværdig jamren over hvor forfærdeligt Danmark siden tidernes morgen har ageret $\mathrm{i}$ forhold til sin tidligere koloni:

Så er en landingsbane for kort, så 
har man ikke gjort nok i hval-forhandlinger, så mangler der fængselspladser, så tvinger man Hjemmestyret til at købe alle varerne i Danmark, så blev man sparket ud af kajakkerne, så har man snydt Grønland med Thule, så fik man tvunget Grundloven ned over hovederne i 1953. Ja, og i 1721 gik det hele lige så godt - men så sejlede Hans Egede til Grønland, grundlagde Godthåb, og ødelagde det hele!

Min folketingskollega, Lars-Emil Johansen, er uofficiel Grønlandsmester i jammer: Han vil have mere end de 3,2 mia., idet han har haft lommeregneren fremme og fundet ud af, at Danmark skylder Grønland 65 milliarder kroner. Og de milliarder skal afleveres - for det er de penge, Danmark har sparet på NATO-medlemskabet ved at lade amerikanerne bruge Thule. En anden af mine bekendte fra Grønlandsk-Dansk Selvstyrekommission, borgmesteren i Jakobshavn, Anthon Frederiksen, udtrykte det engang under en debat i Kommissionen således: "Danskerne har i århundreder grinet hele vejen til banken".

\section{Grønlands Mandela}

Men det tragikomiske ved det hele er, at dette altså er Rigsfællesskabet anno 2008. Det er sådan, at man fra mange ledende grønlandske politikeres side ser på Danmark og danskerne - som nogen, der går og griner hele vejen til banken.
Men det er ganske uantageligt at forfladige Rigsfællesskabet på den måde. At gøre Rigsfællesskabet til noget så vulgært. Og det er uantageligt at fuppe på den måde. Desværre er mange unge grønlændere hoppet på fup-historierne.

Jeg møder i mange sammenhænge disse unge - såvel her som $\mathrm{i}$ Grønland, og bliver dybt frustreret over at høre dem jamre på samme måde som deres politiske forbilleder - frem for friske og frejdige at tage fat på problemerne. Og jeg får af og til lyst til at tage fat i kravetøjet på dem, ruske dem - og sige: Så tag jer dog for pokker sammen! Det tragiske ved det hele, er at det faktisk er lykkedes for politikere som Anthon Frederiksen, Lars-Emil Johansen, Kuupik Kleist, Johan Lund-Olsen, Minninguaq Kleist at få den grønlandske ungdom til at få en fornemmelse af, at grønlænderne er ofre og danskerne er bødler. Det er lykkedes disse politikere, som de dygtige manipulatorer, de er, at give grønlænderne offerrollen som 'et undertrykt folk'.

Jeg har oven i købet af unge grønlændere hørt Grønlands grand-ol'man, Jonathan Motzfeldt, beskrevet som 'Grønlands Mandela'. Underforstået, at grønlænderne er de undertrykte negre, mens danskerne er en slags nazister, der holder grønlænderne i en slavelignende tilstand. I øvrigt en ganske særlig nedrig sammenligning, når man betænker, at den hårdt prøvede 
Nelson Mandela måtte lide under 27 års ophold i Sydafrikas mest usle fængsel, mens Motzfeldt i 27 år har opholdt sig på business-class. Jeg vil tilføje, at Motzfeldt på ingen måde kan lastes for denne groteske sammenligning, som jeg, hvis jeg kender dette lødige menneske ret, tror, at han gerne ville have sig frabedt.

Desværre er det ikke kun unge grønlændere, der tilsyneladende er hoppet på den med offer og bøddel. Der er nemlig også i bunkevis af førende danske personligheder, herunder politikere, der er ved at falde over hinanden og egne ben for til enhver tid, undskyldende og hændervridende at stå parat med pengeposen for at bøde på alle de uretfærdigheder, vi har påført Grønland.

Men jeg må sige, at hvis det er på dén måde, man vil be-lyve sit folk til at kræve selvstændighed, synes jeg det er billigt og gement. Og hvis man får gennemført selvstændighed ved at fuppe folk til at fortælle løgnehistorier om Danmark og få grønlændere til at hade danskerne og bilde hinanden ind, at man er undertrykte stakler, synes jeg det er forargeligt. I så fald siger jeg ikke held og lykke med foretagendet. I så fald vil jeg bekæmpe selvstændigheden med næb og kløer. For så er projektet blevet til på en uværdig måde. Uværdigt for Rigsfællesskabet.

I forbindelse med mit arbejde i Grønlandsk-Dansk Selvstyrekommission er jeg blevet betegnet som 'Grønlandskritisk'...., og det er ble- vet sagt, at jeg stikker kæppe i hjulet på alt, der berører Grønland. Det er beskrivelser, jeg finder såvel dybt irriterende som unfair.

Vel er jeg ej Grønlandskritisk, og vel stikker jeg ikke kæppe i hjulet på 'alt, der berører Grønland'. Jeg har derimod arbejdet nidkært og engageret i kommissionen, fulgt møderne, læst på stoffet, deltaget aktivt, medvirket! - men er altså, efter en grundig analyse og adskillige Grønlandsdebatter i vores folketingsgruppe, nået frem til, at vi ikke kan anbefale, at Grønlands Selvstyre uden videre får foræret alle ressourcer, som vi mener, tilhører Rigsfællesskabet og bør komme os alle til gode.

\section{Pamperi og nepotisme}

Nej, jeg er ikke Grønlandskritisk. Til gengæld er der ingen tvivl om, at jeg er stærkt Siumutkritisk, og det altså af ganske almindelige politiske årsager. Partiet Siumut, som også er repræsenteret i Folketinget, er for mig lige så rigtigt som legalt at modarbejde som det er, når jeg med stor fornøjelse modarbejder Enhedslisten.

I knapt 30 år har Siumut haft magten i Grønland. Det er alt, alt for længe for et politisk parti at sidde på magten i et hvilket som helst land (der er vel formodentlig kun Fidel Castros parti på Cuba, der uden sammenligning i øvrigt - slår Siumuts rekord), for en så lang periode, stort set med de samme perso- 
ner på topposterne, må nødvendigvis føre til magtfuldkommenhed, arrogance og nepotisme, præcis de dårligdomme, som Grønland i dag netop lider af.

I et vestligt demokrati er Siumut måske lidt at sammenligne med det svenske socialdemokrati, som i en menneskealder styrede 'Folkhemmet Sverige'. Den samme nepotisme, det samme kammerateri, det samme infame pamperi, de samme mentale tommelskruer på alle, der dristede sig til at udfordre styret. Hvor har jeg dog i de sidste år modtaget mange henvendelser fra grønlændere, som fortæller, at de er godt og grundigt trætte af forholdene, men, da de ikke ønsker at ødelægge deres karrieremuligheder, har de ikke nogen særlig lyst til at stå offentligt frem. Her ophører så $\mathrm{i}$ øvrigt også lighederne mellem Tage Erlanders Sverige og Lars-Emil Johansens Grønland.

For mens Socialdemokraterna i den lange periode grundfæstede Sverige med en bundstærk økonomi og skabte verdens bedst uddannede folk og bedste social- og sundhedsvæsen, har Siumut formået at placere Grønland i bunden af stort set alle nordiske statistikker.

Siumut fik samtidig, ved sin chauvinistiske retorik - læs eksempelvis bare Lars-Emil Johansens tale til Siumuts jubilæumsfest for nylig - skabt et nedrigt had til Danmark og en glødende foragt for Rigsfællesskabet. Siumut 'grønlandiserede'.

\section{Ud med dansk}

Så latterligt rasende var Lars-Emil Johansen og Co. på alt, hvad der var dansk, at man ikke længere ville acceptere det danske sprog. Jeg husker tydeligt, hvordan Siumut for et kvart århundrede siden stillede det retoriske spørgsmål: "Hvorfor skal vores første fremmedsprog være dansk - hvorfor skal det ikke være engelsk?” Og for mange lød det spørgsmål vel egentlig ganske fornuftigt - vel at mærke, hvis initiativet var blevet fulgt op af en intensiv engelskundervisning af den grønlandske ungdom. Sådan gik det bare overhovedet ikke. Man afskaffede nemlig stort set dansk, men satte ikke engelsk i stedet. Derved efterlod Siumut en hel generation af unge på et mellemtekniker-niveau af den banale årsag, at de ikke havde de nødvendige sprogkundskaber.

For 20 år siden og tidligere var det dansksprogligt særdeles velfunderede grønlændere, der mødte frem til videregående uddannelser i Danmark, og disse unge havde ikke de fjerneste vanskeligheder med at klare sig i konkurrencen med deres danske kammerater. De unge grønlændere som i dag skal videreuddanne sig, kan derimod hverken engelsk eller dansk på det nødvendige niveau. De ankommer til Danmark efter endt grundlæggende uddannelse fra Godthåb, Jakobshavn eller Holsteinsborg - velbegavede og ofte med fine karakterer, men støder så 
ved ankomsten til Danmark med et brag mod en betonmur, når de indser, at de slet ikke kan klare det sproglige på de mellemlange eller videregående uddannelser. De fleste af de ganske få det lykkes for, ender dog, efter endt uddannelse, med at blive i Danmark - så glimrende beskrevet i TV-dokumentaren Flugten fra Grønland.

Samtidig fik stemmen fra Siumut - for det desværre den eneste, vi har hørt herhjemme i 25 år - danskerne til at tro, at grønlændere ikke holder af Rigsfællesskabet. Igen en fuphistorie, for der er et andet Grønland, hvor kærligheden til Danmark og det danske folk er aldeles usvækket. I de kredse kluklér man og ryster samtidig fortvivlet på hovederne af Siumuts sværmeriske planer om at rive Grønland løs fra Rigsfællesskabet. Og jeg kender dette andet Grønland godt nok til at vide, at planerne ikke så let som Siumut forestiller sig bliver virkeliggjort. Når folkeafstemningen om egentlig grønlandsk selvstændighed finder sted, kan Siumut vise sig at vågne op med svære tømmermænd. Jo, jeg er godt gal på Siumut! Rasende og indigneret som jeg er over den elendige sociale og uddannelsesmæssige situation, der kendetegner Grønland, og som Hjemmestyret - ikke Staten! - har det fulde ansvar for. Vred over den nepotisme og korruption, der kendetegner Grønland, og jeg mener faktisk, at jeg har fuld ret - ja, ligefrem pligt - til at reagere, når de tragiske sager popper op. Dels fordi alle borgere i Grønland er danske statsborgere, dels fordi Staten, og dermed danske skatteydere, er medfinansierende.

I Dansk Folkeparti, som jeg repræsenterer i Grønlandsk-Dansk Selvstyrekommission, ser vi meget gerne Rigsfællesskabet fortsat altid. Der er så meget, der binder danskere og grønlændere sammen - historisk, følelsesmæssigt og familiemæssigt, at det for begge parter efter tre århundreders tæt samhørighed vil være en historisk katastrofe at bryde båndene.

\section{Unik beredvillighed}

Det er altså urimeligt, at det i stor stil er lykkedes for denne lille gruppe af grønlandske politikere dels ved drømmerier om store oliefund og dels ved hjælp af urimelige angreb på Danmark og det danske folk at rejse kunstige barrierer mellem grønlandsk og dansk - en barriere, som ikke generelt afspejler grønlandsk sind, og som jeg ikke et sekund tror på, har vundet gehør i det grønlandske folks flertal.

Jeg finder at en egentlig grønlandsk selvstændighed, alene baseret på håb om selvbårenhed som følge af store oliefund, bør give anledning til stor utryghed i det grønlandske folk. Og jeg finder at hvis det en dag skulle lykkes de grønlandske politikere at få trukket Grønland ud af Rigsfællesskabet, vil 
det gøre Grønland til en sårbar deltager i den internationale sikkerhedspolitik.

En vigtig del af diskussionen i Selvstyrekommissionen har været omkring de økonomiske forhold, og det er min opfattelse, at de danske delegationsmedlemmer generelt ikke har ageret i overensstemmelse med Danmarks og det danske folks interesser. Det burde nemlig være evident, at Danmarks Riges undergrund som en selvfølge tilhører Danmarks Rige, og at alle borgere i Rigsfællesskabet får del i de værdier, der måtte findes i undergrunden. Sådan forholder det sig jo allerede, når det gælder de værdier, der hentes op fra Danmarks undergrund samt i forhold til de værdier, som skabes af danske borgere - og som solidarisk, år efter år, videregives, så de også kommer Grønland til gode.

Og sådan har det faktisk altid forholdt sig: Enorme subsidier blev forud for Hjemmestyrets indførelse overført fra Danmark til Grønland i årene mellem 1953 og 1979, hvor de grønlandske kommuner opnåede fuld udligning i forhold til danske kommuner. Også i årene frem til 1953, mens Grønland endnu havde kolonistatus, overførtes store subsidier fra Staten til Grønland. I alle årene, som det fremgår af DIIS-rapporten fra 2007, Afvikling af Grønlands Kolonistatus 1945-54, har Danmark på intet tidspunkt i historien profiteret på Grønland, som tilfæl- det ellers normalt har været i forholdet mellem koloniherre og koloni.

Danmark har derimod til stadighed - uegennyttigt og ihærdigt - arbejdet på, år efter år, at forbedre forholdene for Grønland og for det grønlandske folk. Som stat har Danmark, i modsætning til mange andre tidligere kolonimagter, således ikke det allermindste at skamme sig over, når det gælder Grønland. Folketinget og Regeringen står pr. definition til enhver tid og med et smil parat til at assistere og yde bistand, når som helst Grønlands Hjemmestyre skulle ønske det.

Denne unikke beredvillighed betragtes fra de danske myndigheders side end ikke som en byrde, men som en kær opgave. På samme måde forholder det sig med det danske folk, som via skattebilletten og uden at mukke sender knapt 3,5 mia. kroner af sted til Grønlands Hjemmestyre, svarende til 66.000 kroner pr. indbygger i Grønland fra spædbarn til olding.

Burde de regerende grønlandske politikere egentlig ikke anerkende denne enestående imødekommenhed og denne 300 års kærlighedserklæring til Grønland og det grønlandske folk - frem for denne kroniske surhed og denne barnagtige og uværdige jamren?

Søren Espersen er medlem af Folketinget for Dansk Folkeparti 